UDC 379.85

https://doi.org/10.17721/2308-13

5X.2020.59.19-24

Gunel Valiyeva Baku State University, Baku, Azerbaijan

\title{
METHODOLOGY OF CONDUCTING RECREATIONAL ZONING AND OPPORTUNITIES FOR ITS APPLICATION IN AZERBAIJAN
}

Aim: The main aim of the article to analyze the principles and methodology of recreational zoning, the related theories, as well as the factors, which must be successively considered in this process.

The methodological basis of the article is the theoretical provisions set forth in the works of Azerbaijani and foreign scholars in defining theoretical and methodological peculiarities of the state programs, international experience in the organization of Recreation Zones.

Results: The carried work also demonstrates the feasibility of the conduction of recreational zoning in Azerbaijan, with distinguishing sub-regions within the boundaries of touristic-recreational region of Gusar. The tourism- recreation zone of Gusar specifically predicts the main directions of development of the microdistrict by type of tourism. In accordance to the selection of areas for the Gusar tourism-recreation zone are taken into account the potential for the development of various types of tourism, as well as the suitability for the joint organization of many services. From this point of view, in the formation of recreational tourism zones graphic of dependence is considered the basis for the development of areas. The article shows that the advantages of applying this dependence graphic is suitable for the Gusar recreation and tourism zone. At the same time, the separation of Chilagir-Urva-Khuray, Anig-Laza, Hazra-Sudur micro-recreation regions in the Gusar recreation-tourism zone is due to the existence of similar natural-geographical conditions and conditions for the organization of different types of tourism. The structure of employment is 
dominated by agriculture and, in part, by tourism. Potato-growing and livestock are the main agricultural sectors.

Scientific novelty: The practical significance of the article is the selection of areas suitable for tourism development in the Gusar Tourism and Recreation Zone, and the forecasting of tourism development trends, taking into account the ecological balance.

Keywords: recreational region, recreational resources, natural, socioeconomic, anthropogenic resources, economic efficiency, Gusar recreation-tourism zone, recreational region, recreational resources, natural, socioeconomic, anthropogenic resources, economic efficiency, the model of recreation-tourism.

References:

1. "Azerbaijan" newspaper. Strategic Roadmap for Development of Specialized Tourism Industry in the Republic of Azerbaijan. Baku,2016, December 17. (In Azerbaijani)

2. Resolution of the Cabinet of Minister of the Republic of Azerbaijan on the establishment of Khizi-Khachmaz, Guba and Gusar tourist and recreational zones in the Republic of Azerbaijan. (2016). №. 286 (August 1). (In Azerbaijani)

3.Budagov B.A. Natural monuments of Azerbaijan. Baku:

Science, 1990, p. 180. (In Azerbaijani)

4. Dargahov V.S. Recreation and tourism resources. Baku: MBM, 2008, p. 214. (In Azerbaijani)

5. Soltanova H.B. Tourism and its development in the Republic of Azerbaijan. Monography. 
Publishing House of AzTU. Baku, 2015, p.264. (In Azerbaijani)

6. Aleksandrova A.Yu. International tourism. Moscow: Aspect Press, 2002, p.470. (in Russian)

7. Vendina O.I. Recreational condition and the optimization ways of territorial organization of recreational activity. / Theoretical problem of recreational geography. Moscow, 1989 (in Russian)

8. Kuskov A.S., Golubeva V.L., Odintsova T.N. Recreational geography. Moscow: Flinta, 2005, p.496. (in Russian)

9. Mironenko N.S., Pirozhnyk I.I., Tverdokhlebov I.T. Theoretical foundations of recreational zoning. / Theoretical problems of recreational geography. Moscow, 1989 (in Russian)

10. Nikolaenko D.V. The evolution of the development of the region and the formation of its recreational specialization. / The state and prospects of tourism development in the CIS. SPb .: 2000. (in Russian)

11. Salmanov A.A. Geography of resort areas of the seaside zone of Azerbaijan. Abstract of the dissertation work. Baku, 1973, p.19. (In Azerbaijani)

12. Tourism, development and growth: the challenge of sustainability. London, 1997, 302 p. (In English)

13. Ceballos-Lascuráin, $\mathrm{H}$. Tourism, ecotourism and protected areas: the state of nature-based tourism around the world and guidelines for its development. Cambridge, 1996, 301 p. (In English) 
14.Towner J. An Historical Geography of Recreation and Tourism in the Western World 1540-1940, 1996, 312 p. (In English)

Надійшла до редколегії 20.10.2020 